\title{
VENDOR TRUST INFLUENCING CRM STRATEGIC IMPLEMENTATION PROCESS
}

\author{
Assion Lawson-Body, University of North Dakota, assion.lawsonbody@mail.business.und.edu \\ Lori Willoughby, Minot State University, Lori.Willoughby@ minotstateu.edu \\ Kinvi Logossah, Université des Antilles et de la Guyane, kinvi.logossah@ martinique.univ-ag.fr \\ Fred Celimene, Université des Antilles et de la Guyane, Fred.Celimene@martinique.univ-ag.fr
}

\begin{abstract}
There is a significant body of evidence that many information systems (IS) implementation projects end in success. Despite numerous IS implementation project successes, there has also been a plethora of failures. This paper examines the impact of vendor trust on customer relationship management (CRM) implementation process. Grounded in available literature on vendor trust and IS implementation theory, a conceptual model was composed to examine the impact of vendor trust on peer influence, top management support, and user participation, which, in return, may impact the CRM implementation performance. Data were collected from interviews of Women Business Centers (WBCs) and Small Business Development Center (SBDC) consultants in North Dakota to test the hypotheses. The results show that vendor trust has a positive impact on peer influence and top management, which positively impact the CRM implementation success. However, the impact of vendor trust on user participation is different, as it has a negative impact on the CRM implementation success. This is due to the nature of CRM system which involves not only internal user participation, but also external user participation. The implications of the results for the study are discussed.
\end{abstract}

Keywords: CRM, Trust, Implementation of IT, User Participation, Peer Influence, Top Management

\section{INTRODUCTION}

The use of IT adds a new dimension to relationship marketing (RM), known as customer relationship management (CRM) [21]. Existing theory contributes to RM and helps to transform it into a general marketing theory. RM has established itself as an information system (IS) reference discipline and has been modified to become CRM. Since the success of a CRM depends on its participants, its implementation drivers should create a sustainable competitive advantage for firms in today's fast changing and evolving organizational environments [10]. IT implementation is a core competency that may determine the competitiveness of firms in information intense industries [6]. The changing corporate environment has resulted in a need to better understand and improve the process of implementing IT [13]. A number of studies have made the point that IT has strategic implication and that its implementation has to be aligned with the firms' competitive needs [6].

IT implementation success or failure is not manifested in the same way in every situation, industry, or business sector. One of the reasons behind the failure of CRM strategic application is the inefficiency when implementing it [15]. According to Gartner Group, the rate of successful CRM implementations is below 30\% [8]. None of the existing models to guide companies in the implementation of CRM strategy has succeeded in all situations because each company is different, has its own culture and business processes [15]. Consequently, there is no common way to consider that will solve all company's implementation problems [15]. Each company CRM implementation strategy requires a unique and innovative approach that will be difficult to be reused in the situation of another company. Also, none of the previous studies of CRM implementation strategy have focused on the role of the CRM software or systems provider trust. In other words, the existing CRM implementation models have not considered the impact of vendor trust on the success or the failure of the implementation.

The objective of the study is to examine the impact of vendor trust on a success of CRM implementation process. A research model will show the role a vendor trust can play on IT 
implementation drivers which need to be considered for CRM implementation. The model will examine the impact of vendor trust on contextual, organizational and user characteristics, which, in return, may have impact on the implementation success. Next, the research model will be tested using qualitative data collected from participants of a CRM implementation project.

\section{CRM STRATEGIC PERSPECTIVES}

Many authors have defined CRM using different streams and there is no common agreement on the different definitions of CRM. Among those, Day and Van Den Bulte (2002 cited in [17]), defined CRM as a cross-functional process for achieving a continuing dialogue and conservations with the customers, across all their contact and access points, with personalized treatment of the most valuables customers, to increase customer loyalty $[17,1]$. The importance of CRM has been revealed by different authors; principally, CRM plays a major role in the competence development of small businesses (SBs) [17, 10].

Researchers have also studied the effective acceptance of CRM technology using theoretical Technology Acceptance Model (TAM) of Davis (1989) and the measurement of IS success by adopting Delone and McLean IS Success Model [1]. Davis' model is based upon the Theory of Reasoned Action. According to the TAM, usage behavior is determined by intentions towards using the technology, while intention is determined by two related beliefs such as perceived ease-of-use and perceived usefulness [1]. Variables such as social factors, organizational factors and individual factors often have been mentioned to study the successful acceptance of CRM systems [1]. Organizational training on CRM, user participation in the implementation process, and accurate expectations setting, are factors used to assess the acceptance of the CRM system [1].

This study examines a methodical IT implementation approach of CRM implementation. The rationale behind this research is that existing implementation theory should be extended to include the vendor trust as a source of identified CRM implementation success or failure. So that, including the vendor trust in studies of CRM implementation provides a more complete understanding of the phenomenon.

\section{IT IMPLEMENTATION THEORIES}

Theories of IS implementation are a core research area in today's IS environment [22]. Several theoretical perspectives are relevant for the study of IT implementation. Each of those theories focused on a group of specific constructs or the relationships between those concepts to explain the implementation outcomes such as system use, user satisfaction, user participation, user acceptance of the technology, etc. [22]. The theory of strategic information systems planning contains a link between plan and implementation which suggests that a more useful IS plan produces greater implementation plan [9].

According to the findings of Aubert et al, (2004), theories of IT implementation contain three factors such as the context in which the implementation is initiated, the execution of the implementation and the final results of the implementation [22]. Current theories conceive of implementation context as fixed and static, and different perspectives on implementation posit different contextual variables [22]. Duh et al. [6] argued that IT learning is part of the core of implementation process and found that post-implementation learning should involve continuing improvements in how effectively IT is utilized [6].

Implementation begins much earlier than current theories have assumed and should be considered to consist of two distinct but related processes: the acquisition of IS and their deployment in the organization [22]. Bruque and Moyano [4] used qualitative analysis to identify the factors behind the intensity and speed of IT implementation in SBs. They found that there are a number of internal factors that influence the success of IT implementation process. The implementation is motivated by the growth experienced by the SBs [4]. Growth makes it necessary for SBs to implement new technological solutions [4].

The introduction of IS implementation often leads to changes in the organizational structures, the nature of managerial jobs, the locus of decisionmaking, the level of centralization, and the nature of management process for control and coordination [19]. Sharma et al., [19] extended current research on IS-enabled organizational change and drew on configuration theory to develop propositions identifying drivers of IS implementation costs. They examined the effect of organizational changes on IS implementation costs. 
After testing the propositions, they found that interdependencies between changes are key drivers of IS implementation costs.

\section{VENDOR TRUST}

Trust is a multidimensional phenomenon which has different interpretations in many disciplines such as social sciences, organizations, computer sciences, information systems, e-commerce, and others [16, 2].

Trust in the vendor or vendor trust also has been conceptualized in several ways. McKnight et al., [14] has defined vendor trust as a multidimensional construct with two inter-related components, such as trusting beliefs which is perceptions of the competence, benevolence, and integrity of the vendor, and trusting intentions that is a decision to make oneself vulnerable to the vendor. Furthermore, McKnight et al., [14] proposed three factors to build vendor trust: structural assurance which means customer perceptions of the safety of the vendor web environment, perceived web vendor reputation, and perceived web site quality. Structural assurance is an institution-based trust construct, and comes from the sociological tradition because sociologists found that trust in people is supported by the institutional structures that create an environment that feels safe and secure to participants [14]. Reputation means that one assigns attributes to a person based on second-hand information about them [14]. Reputation can be an important trust building factor for vendors, particularly in the initial trust phase [14]. In the initial phase of trust development, the basis of trusting beliefs or trusting attitude cannot be personal experience with the other party, because the parties have no relationship history [14]. Rather, initial trust forms quickly based on whatever information is available [14].

\section{THE RESERACH MODEL AND HYPOTHESES DEVELOPMENT}

Figure 1 shows the research model for the implementation of a CRM software program. The research model postulates that implementation of CRM software program success or failure is determined by three factors. They are: 1) contextual characteristic's factor of peer influence, 2) organizational characteristic's factor of top management support, and 3) individual characteristic's factor of user participation. Vendor or software provider trust may have an impact on those three factors which, in return, may have an impact on implementation success.

The peer influence is drawn from the findings of Aubert et al, (2004 cited in [22]). The top management support is derived from the study of Sharma et al., [19]. Finally, the user participation is chosen from the study of Wybo [22]. In the research model of this study, peer influence, top management support, and user participation are dependent variables to trust and independent variables to implementation success. Each of them is discussed below.

\section{Peer Influence}

When a firm implements a CRM system, other industry firms feel the pressure or are influenced by using the same system because they do not want to be behind [3]. The primary motivation behind CRM implementation is not to earn greater revenue, but to improve the ability to create value for customers through service quality [21].

Barney (1991) proposed that the resource-based view (RBV) theory suggests IT could help a firm obtain competitive advantage and enhance firm performance [20]. IS researchers argue that peer competitors may easily duplicate investments in IT resources by purchasing the same hardware, software and network, and hence resources per se do not provide sustained firm performance [20]. This also occurs because many IT investments are easily duplicated by peer competitors resulting in the same industry competitive situation but at an increased level of cost [12]. Rather, it is the manner in which peer firms leverage their IT investment to create unique capabilities that impact a firm's overall performance [20]. Santhanam and Hartono [20] state that resources can be easily duplicated, but a unique set of capabilities mobilized by a firm cannot be easily duplicated and will result in increased firm performance. A successful CRM system implementation may be a capability that peer firms can use to take advantage of new opportunities [3]. During the CRM implementation process, many firms search for information about existing vendors who did the implementation for their peer. The fact that the existing vendors did the implementation before for peer raises the level of initial trust. Therefore we posit:

H1: The vendor trust will have a positive effect on peer influence. 
$\mathrm{H} 2$ : The peer influence will have a positive effect on the CRM implementation success.

\section{Top Management Support}

All the leading research read for the purpose of this study seemed to share a strong belief in the importance of management support for the implementation of IT $[9,3]$. The top management should play the role of change agent by convincing and selling the merits of the implementation of the new CRM to those who are at the operational and knowledge worker levels. Those on top of the organization must become the main promoters of CRM and must motivate the commitment of all other levels of the company [15].

Managers should strive to determine the informational needs of their employees and develop positive user beliefs about the system [1]. This can be accomplished when managers focus on the development of accurate expectations regarding system usage and benefits, so that CRM users have an unambiguous picture of what management expects from system implementation [1].

The vendor technical IT capability, knowledge and skills needed to develop software and to deploy IT effectively in order to meet company's strategic business objectives can be considered as another asset to the vendor trust-building stimuli. Finally, the vendor's views about the client visits to their premises can help gain trust from the top management team. As such, we propose the hypothesis below:

H3: The vendor trust will have a positive effect on top management support.

H4: Top management support will have a positive effect on the CRM implementation success.

\section{User Participation}

Barki and Hartwick (1989) and Kappelman and McLean (1991) defined user participation as the observable behavior of users during the implementation process of a system [11]. User participation refers to the behavior and activities that the target users or their representatives perform in the system implementation process [11]. Users should take part in the system design and implementation phase, so as to commit themselves and develop realistic expectations about the system [1]. Attention should be paid to the innovative characteristics of users in the recruitment and hiring process, to the demographic composition of the users (age and education), as younger and more educated users are expected to be more familiar with new technology implementation process [1].

User participation is linked to user responsibility. Implementation participant must accept responsibility which is a positive duty, and tasks should be assigned to specific individuals [9]. Responsibility is a multidimensional concept because it covers responsibility for implementation on time, within budget, with intended benefits, of high priority projects, for short-term benefits from initial projects, and personnel rewards from successful implementation [9].

Information and data about the vendor realizations, skills, and knowledge should be made available to the users during the implementation process. That should allow users to build initial trust on the vendor during the implementation process. One of the implementation phases where there are more contacts between the vendor and the users is the training. The vendor teaching capability during the training is usually evaluated by the users. The quality of knowledge gained from the vendor about the use of the CRM system is another way that can be used to assess the vendor trust during the user participation process. The vendor contribution to the learning process of users should also be taken into account. Thus, it is hypothesized:

H5: Vendor trust will have a positive effect on user participation.

H6: User participation will have a positive effect on the CRM implementation success. 


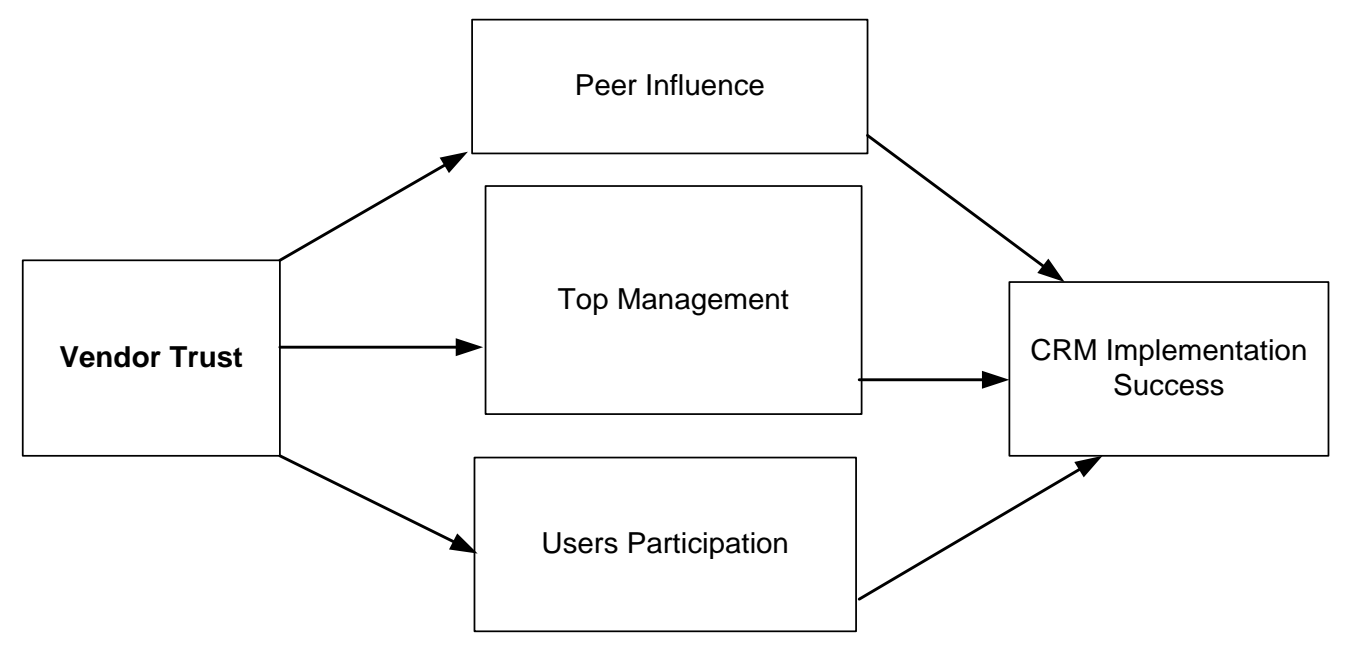

Figure 1. Research Model

\section{METHODOLOGY: MULTIPLE CASE STUDIES}

This research focuses on the implementation of CRM system software by the North Dakota SBDC. Interview data was collected from consultants of SBDC and Women Business Centers (WBCs).

For the qualitative analysis, multiple case studies were conducted. In total, 13 participants in the implementation process were asked to participate in the multiple case studies. The interviews were held individually with each of the participants for about one hour. The interviews were tape-recorded, and the texts of the interviews were transcribed and entered into Windows Word software. To help conduct the interviews, an interview guide was used. The study used content analysis to analyze the data obtained from a sample of CRM implementation participants. Content analysis is a technique used to analyze qualitative data.
Chi-square is used as a statistical test in this paper, because the data are in the form of raw frequency counts of things in two or more mutually exclusive and exhaustive categories [5]. The interview data have been transformed in quantitative data by counting the negative and positive messages about each category or variables of the research model. The dependent variable (CRM implementation success) and the independent variables (vendor trust, peer influence, top management support, and users participation) have been used as categories. Since chi-square is a lot like percentage, it extrapolates a population characteristic (a parameter) from the sampling characteristic (a statistic) similarly to the way percentage standardizes a frequency to a total column $\mathrm{N}$ of 100 [5]. The number of messages counted was converted into percentages as if there were 100 messages in each category of the independent or dependent variable for comparability. 


\section{RESULTS AND DISCUSSION}

Impact of the Vendor Trust on Peer Influence

As shown in Table 1, the hypothesis which states that vendor trust will have a positive effect on peer influence, was significant $(48.58$ at $\mathrm{p}<0.001)$. This result corroborates with certain aspects of the literature review because vendor trust is an antecedent to peer influence in CRM implementation. Software demonstration and how the work is done for the partners or competitors can help the vendor to increase the level of trust from the implementation team. The vendor's opinions about references from their previous clients are useful to them in achieving trust from the client.

Table 1. Number, Percent, and Chi-square of the impact of vendor trust on peer influence

\begin{tabular}{|c|c|c|c|c|}
\hline $\begin{array}{l}\text { Coded } \\
\text { Messages }\end{array}$ & Number & $\begin{array}{c}\text { Percentage } \\
(\%)\end{array}$ & $\begin{array}{l}\text { Number of } \\
\text { respondents }\end{array}$ & $\begin{array}{c}\text { Chi- } \\
\text { Square }\end{array}$ \\
\hline $\mathrm{CSC}$ & 27 & 79 & 11 & \multirow[t]{3}{*}{$11.76^{* * *}$} \\
\hline $\mathrm{CSNC}$ & 7 & 21 & 2 & \\
\hline Total & 34 & 100 & 13 & \\
\hline APA & 30 & 73 & 9 & \multirow[t]{3}{*}{$8.80 * * *$} \\
\hline APNA & 11 & 27 & 3 & \\
\hline Total & 41 & 100 & 12 & \\
\hline GAD & 25 & 83 & 10 & \multirow[t]{3}{*}{13.33 *** } \\
\hline GAND & 5 & 17 & 2 & \\
\hline Total & 30 & 100 & 12 & \\
\hline UCI & 36 & 78 & 9 & \multirow[t]{3}{*}{$14.69 * * *$} \\
\hline UCNI & 10 & 22 & 4 & \\
\hline Total & 46 & 100 & 13 & \\
\hline \multicolumn{4}{|c|}{ The total chi-square value for Table 1 is } & $48.58 * * *$ \\
\hline
\end{tabular}

\section{Impact of the Peer Influence on Implementation Success}

The results presented in Table 2 (37.41 at $\mathrm{p}<0.001)$ support hypothesis 2, which states that peer influence will have a positive effect on implementation success. Our findings have indicated that peer influence is a factor which impacts the decision to initiate the implementation of CRM software. This finding about peer influence corroborates many of the views collected during our study. Before implementing a new system, some companies investigate the systems used by their peers and discover what systems are best recognized in their industry. To reach that goal, they gather data to identify what their peers were using. They usually found different options because some companies may use a standard system, and several companies may use systems which were privately designed and proprietary to them. Actually, peer influence has been linked to competitive pressure in many studies. Firms feel the pressure of knowing that other competitors throughout their industry are implementing, or have already implemented, the new CRM technology.

Table 2. Number, Percent, and Chi-square of the impact of peer influence on implementation success

\begin{tabular}{|l|c|c|c|c|}
\hline $\begin{array}{l}\text { Coded } \\
\text { Messages }\end{array}$ & Number & $\begin{array}{c}\text { Percentage } \\
(\boldsymbol{\%})\end{array}$ & $\begin{array}{c}\text { Number of } \\
\text { respondents }\end{array}$ & $\begin{array}{c}\text { Chi- } \\
\text { Square }\end{array}$ \\
\hline CSC & 17 & 81 & 8 & \multirow{2}{*}{$8.04 * * *$} \\
CSNC & 4 & 19 & 3 & \\
\hline Total & 21 & 100 & 11 & \multirow{2}{*}{$8.1 * * *$} \\
\hline APA & 29 & 72.5 & 10 & \\
\hline APNA & 11 & 27.5 & 3 & \\
\hline Total & 40 & 100 & 13 & \\
\hline
\end{tabular}




\begin{tabular}{|c|c|c|c|c|}
\hline GAD & 26 & 76 & 8 & \multirow[t]{3}{*}{$9.52 * * *$} \\
\hline GAND & 8 & 24 & 5 & \\
\hline Total & 34 & 100 & 13 & \\
\hline UCI & 34 & 75.5 & 9 & \multirow[t]{3}{*}{$11.75 * * *$} \\
\hline UCNI & 11 & 24.5 & 4 & \\
\hline Total & 45 & 100 & 13 & \\
\hline \multicolumn{4}{|c|}{ The total chi-square value for Table 2 is } & $37.41 * * *$ \\
\hline
\end{tabular}

\section{Impact of Vendor Trust on Top Management Support}

The results presented in Table 3 (86.16 at $\mathrm{p}<0.001)$ confirm hypothesis 3 that vendor trust will have a positive effect on top management support. Initial trust with the vendor is appropriate to the CRM implementation process because the company's top management may trust based only on indirect or partial experience. The top management can acquire a sense of the vendor and its representatives from face-to-face discussions. Therefore, the element of trust during CRM implementation process is difficult to develop because the top management access to trust-building stimuli is limited to what can be observed on the web site, from the interactions with the vendor and from the performance of the vendors when working for other firms. Vendor trust can be built also based on the existing relationships between the vendor and the top management.

Table 3. Number, Percent, and Chi-square of the impact of vendor trust on top management support

\begin{tabular}{|c|c|c|c|c|}
\hline $\begin{array}{l}\text { Coded } \\
\text { Messages }\end{array}$ & Number & $\begin{array}{c}\text { Percentage } \\
(\%)\end{array}$ & $\begin{array}{c}\text { Number } \\
\text { of } \\
\text { respondents }\end{array}$ & $\begin{array}{c}\text { Chi- } \\
\text { Square }\end{array}$ \\
\hline WTP & 22 & 73 & 7 & \multirow[t]{3}{*}{$6.53 * *$} \\
\hline WTNP & 8 & 27 & 5 & \\
\hline Total & 30 & 100 & 12 & \\
\hline LPD & 33 & 82.5 & 10 & \multirow[t]{3}{*}{$16.9 * * *$} \\
\hline LPND & 7 & 17.5 & 2 & \\
\hline Total & 40 & 100 & 12 & \\
\hline CIP & 27 & 77 & 9 & \multirow[t]{3}{*}{10.31 *** } \\
\hline CINP & 8 & 23 & 4 & \\
\hline Total & 35 & 100 & 13 & \\
\hline WDC & 32 & 91 & 12 & \multirow[t]{3}{*}{$24.02 * * *$} \\
\hline WDNC & 3 & 9 & 1 & \\
\hline Total & 35 & 100 & 13 & \\
\hline ARW & 44 & 81 & 10 & \multirow[t]{3}{*}{$21.40 * * *$} \\
\hline ARNW & 10 & 19 & 3 & \\
\hline Total & 54 & 100 & 13 & \\
\hline $\mathrm{CCA}$ & 20 & 80 & 9 & \multirow[t]{3}{*}{$9 * * *$} \\
\hline CCNA & 5 & 20 & 3 & \\
\hline Total & 25 & 100 & 12 & \\
\hline \multicolumn{4}{|c|}{ The total chi square value for Table 3 is } & $88.16 * * *$ \\
\hline
\end{tabular}

Impact of Top Management Support on Implementation Success

As shown in Table 4, the hypothesis that top management support will have a positive effect on implementation success was found to be positive (74.2 at $\mathrm{p}<0.001)$. This study shows that top level management and support is needed during the implementation process. The top management team must play the role of coordinator when putting in place the implementation team. It is the 
responsibility of the executive level of the organization to locate the staff that possesses technical expertise that can be used to help the company succeed in the implementation. In this study, the executive plays the role of planning and steering committee since he decides the allocation of resources (financial, materials, time, location of the implementation, etc.) to the different entities involved in the implementation project. The active involvement of high-level executives provides the impetus needed to sustain the implementation of IT [3]. Based on the past experience with the vendor, the top management can develop positive beliefs about the CRM system.
Because some users are familiar with the existing or old systems, the top management must play the role of change agent by selling the implementation's merits to them. That should reduce the resistance to change. Those on top of the organization must become the main promoters of CRM and must motivate the commitment of all other levels of the company [15]. Help from the vendor also can play a role in diminishing the resistance to change.

Table 4. Number, Percent, and Chi-square of the impact of top management support on implementation success

\begin{tabular}{|c|c|c|c|c|}
\hline $\begin{array}{l}\text { Coded } \\
\text { Messages }\end{array}$ & Number & $\begin{array}{c}\text { Percentage } \\
(\%)\end{array}$ & $\begin{array}{c}\text { Number } \\
\text { of } \\
\text { respondents }\end{array}$ & $\begin{array}{l}\text { Chi- } \\
\text { Square }\end{array}$ \\
\hline CIS & 34 & 77 & 10 & \multirow[t]{3}{*}{$13.09 * * *$} \\
\hline CINS & 10 & 23 & 3 & \\
\hline Total & 44 & 100 & 13 & \\
\hline ETC & 28 & 70 & 8 & \multirow[t]{3}{*}{$6.4 * *$} \\
\hline ETNC & 12 & 30 & 2 & \\
\hline Total & 40 & 100 & 10 & \\
\hline SWD & 37 & 82 & 11 & \multirow[t]{3}{*}{$18.68 * * *$} \\
\hline SWND & 8 & 18 & 2 & \\
\hline Total & 45 & 100 & 13 & \\
\hline OPI & 25 & 86 & 10 & \multirow[t]{3}{*}{$15.20 * * *$} \\
\hline OPNI & 4 & 14 & 2 & \\
\hline Total & 29 & 100 & 12 & \\
\hline AWA & 26 & 81.25 & 9 & \multirow[t]{3}{*}{$12.5 * * *$} \\
\hline AWNA & 6 & 18.75 & 4 & \\
\hline Total & 32 & 100 & 13 & \\
\hline WAV & 21 & 78 & 7 & \multirow[t]{3}{*}{$8.33 * * *$} \\
\hline WANV & 6 & 22 & 4 & \\
\hline Total & 27 & 100 & 11 & \\
\hline \multicolumn{4}{|c|}{ The total chi square value for Table 4 is } & $74.2 * * *$ \\
\hline
\end{tabular}

\section{Impact of Vendor Trust on User Participation}

Table 5 shows that hypothesis 5 , which states that vendor trust will have a positive effect on user participation, is not supported $(29.23$ at $\mathrm{p}<0.001)$. The impact of the vendor trust on user participation is found to be negative in this study because of the nature of CRM software. Having a skilled workforce available to the vendor with extensive backgrounds helps to the success of the company. That can be used to gain trust from the users and trigger their participation to the implementation process. The vendor honesty, such as the way the vendor presents the real facts about the work and reacts proactively if something is wrong, can help to gain trust from the users. However, since the nature of CRM software involves its implementation inside and outside the company, the users who have participated in this study are internal to the organization under study. The external users or customers of the company were 
not involved. So the trust was built with the internal

users but not with the external users.

Table 5. Number, Percent, and Chi-square of the impact of vendor trust on user participation

\begin{tabular}{|c|c|c|c|c|}
\hline $\begin{array}{l}\text { Coded } \\
\text { Messages }\end{array}$ & Number & $\begin{array}{c}\text { Percentage } \\
(\%)\end{array}$ & $\begin{array}{c}\text { Number } \\
\text { of } \\
\text { respondents }\end{array}$ & $\begin{array}{c}\text { Chi- } \\
\text { Square }\end{array}$ \\
\hline THA & 12 & 28 & 5 & \multirow[t]{3}{*}{$8.39 * * *$} \\
\hline THAN & 31 & 72 & 8 & \\
\hline Total & 43 & 100 & 13 & \\
\hline TEA & 15 & 33 & 6 & \multirow[t]{3}{*}{$5 * *$} \\
\hline TENA & 30 & 67 & 6 & \\
\hline Total & 45 & 100 & 12 & \\
\hline FCI & 8 & 29 & 6 & \multirow[t]{3}{*}{$5.14 * *$} \\
\hline FCNI & 20 & 71 & 7 & \\
\hline Total & 28 & 100 & 13 & \\
\hline BVR & 9 & 26 & 4 & \multirow[t]{3}{*}{$8.25 * * *$} \\
\hline BVNR & 26 & 74 & 8 & \\
\hline Total & 35 & 100 & 12 & \\
\hline BSR & 12 & 36 & 7 & \multirow[t]{3}{*}{$2.45 * *$} \\
\hline BSNR & 21 & 64 & 5 & \\
\hline Total & 33 & 100 & 12 & \\
\hline \multicolumn{4}{|c|}{ The total chi square value for Table 5 is } & $29.23 * * *$ \\
\hline
\end{tabular}

$* * \mathrm{P}<0.025$

\section{Impact of User Participation on Implementation}

\section{Success}

Table 6 shows the results of hypothesis 6 which states that user participation will have a positive effect on implementation success. This test was found to be negative $(46.89$ at $p<0.001)$. Since the impact vendor's trust on user participation is found to be negative, the user participation has not had a positive effect on the implementation success. Because of the inherent complexity of the CRM package, training users is critical [3]. Not only should training result in greater achievement of the implementation process, but it will also increase the allocation of the necessary resources for training [3]. In this study, training sessions have been organized to favor the user participation to the implementation process. However, the training sessions were directed toward the internal users. None of the external users was convened to the training sessions. Also, the literature has shown that the implementation must incorporate acquisition and the deployment. Most of the users reported that they were involved in the deployment process. But the acquisition level was managed by the executives who finalized the decision of purchasing, by hiring a legal purchasing firm who looked over the licensing agreements, and all legal and contractual status of the proposed system.

Table 6. Number, Percent, and Chi-square of the impact of user participation on implementation success.

\begin{tabular}{|l|c|c|c|c|}
\hline $\begin{array}{l}\text { Coded } \\
\text { Messages }\end{array}$ & Number & $\begin{array}{c}\text { Percentage } \\
(\%)\end{array}$ & $\begin{array}{c}\text { Number } \\
\text { of } \\
\text { respondents }\end{array}$ & \multirow{2}{*}{$\begin{array}{c}\text { Chi- } \\
\text { Square }\end{array}$} \\
\hline CMH & 8 & 27 & 4 & \multirow{2}{*}{$6.53^{* *}$} \\
\hline CMNH & 22 & 73 & 5 & \\
\hline Total & 30 & 100 & 9 & \multirow{2}{*}{$15.15^{* * *}$} \\
\hline TSD & 7 & 18 & 3 & \multirow{2}{*}{} \\
\hline TSND & 31 & 82 & 10 & \\
\hline Total & 38 & 100 & 13 & \\
\hline & & & & \multicolumn{1}{|c}{} \\
\hline
\end{tabular}




\begin{tabular}{|c|c|c|c|c|}
\hline TTJ & 10 & 31.25 & 7 & \multirow[t]{3}{*}{$4.5 * *$} \\
\hline TTNJ & 22 & 68.75 & 6 & \\
\hline Total & 32 & 100 & 13 & \\
\hline DRO & 6 & 21 & 4 & \multirow[t]{3}{*}{$9.96 * * *$} \\
\hline DRNO & 23 & 79 & 7 & \\
\hline Total & 29 & 100 & 11 & \\
\hline WTC & 10 & 24 & 5 & \multirow[t]{3}{*}{$10.75 * * *$} \\
\hline WTNC & 31 & 76 & 8 & \\
\hline Total & 41 & 100 & 13 & \\
\hline \multicolumn{4}{|c|}{ The total chi square value for Table 6 is } & $46.89 * * *$ \\
\hline
\end{tabular}

\section{CONCLUSION}

\section{Theoretical and Managerial Implications}

The results show that four of the six hypotheses found support. Vendor trust has a positive impact on peer influence and top management support which in turn have positive impact on implementation success. However, vendor trust has a negative impact on user participation, which in turn has a negative impact on implementation success.

Trust is a complex concept and has numerous definitions. In this study, trust is the extent to which the buyer believes that the vendor has intentions and motives that are beneficial to him [2]. Vendor trust may not be immediately reflected in business relationships because it takes time for customers to assimilate trust to the vendor. Trust is built over time, and, for a vendor, there is a time lag in obtaining customer trust. In this research, there are antecedents demonstrating that trust in the vendor has been built over time. According to Morgan and Hunt (1994; cited in [2]), trust in business relationships is a key factor for successful longterm partnership relationships. In this study, there is a business relationship between the client and the vendor because both entities have been doing business for a while. Another element which shows that the client has established vendor trust with the vendor is its reputation and credibility that have been built over time. Also, the client develops vendor trust based on personal experience with the other party, because both parties have relationship history.

The results of this study will allow IS implementation experts, managers, participants and sponsors to inform companies and organizations about the impact of vendor trust on the implementation success. These experts have to show companies and organizations reliable methods to minimize CRM implementation failure and to maximize CRM implementation success. Based on the nature of CRM, experts will use the outcomes of this study to continuously demonstrate the contribution of internal users and external clients to the implementation process.

This study added to the understanding and importance of vendor trust during the acquisition and the deployment of a new application into organizations. The findings of this research should be used as a diagnostic tool for implementing new CRM software into organizations. The results of this study show that the challenge for a strategic implementation of CRM systems is its variation from company to company. There is no unique solution for CRM implementation.

Rare is the existing research that has expanded a research model by incorporating vendor trust in the implementation process. This research has the privilege to study the impact of vendor trust on very important implementation success or failure factors such as peer influence, top management support and user participation. Also, this study shows how the trusted-peer influence, the trusted-top management support, and the trusted-user participation can impact the implementation success. The literature review lets us understand that a growing number of studies on CRM implementation success or failure have been carried out. However, many studies have failed to develop a research model examining the impact of vendor trust on the implementation performance. This study expands trust theory and the implementation theory and applies them to the strategic CRM implementation success. 


\section{Limitations}

There were three notable limitations with the study. Firstly, the study focuses on only one state (SBDC and Women Center consultants in North Dakota) and it remains to be seen if the results apply to other states. This may restrict the generalizability of the results. Secondly, SBDC consultants are in the public sectors where the confidentiality and the rules to release personal and professional information are strict. Consequently, it is often fruitless to ask for some information related to the relationship between SBDC consultants and their managers in terms of a new system implementation. Even if a small percentage of consultants maintain such information, it is unlikely that it is readily available to researchers due to suspicions about the intended use. Finally, there were limitations of the questionnaire used, in particular, to the profile of respondents. From certain statements, we became aware that some respondents did not necessarily have a general knowledge about their organization because either they are a part time employee or only their immediate supervisor knows about the CRM system implementation. In addition, based on the nature of CRM systems, it will be more interesting if external clients participate in the study.

\section{Future Directions}

Even though the data we collected for this study focused on SBDC consultants, the research approach could be applied to any group of professionals. Quantitative analysis will be needed to perform more tests with the hypotheses developed in this study. Future research is necessary because this research model must be tested further. Many exciting research issues are being addressed and some are yet to be addressed, and we hope that this paper inspires others to do future research by expanding or enhancing this research model.

\section{REFERENCES}

1. Avlonitis G. J. and Panagopoulos N. G. (2005). "Antecedents and consequences of CRM technology acceptance in the sales force" Industrial Marketing Management, Vol. 34, pp. 355-368.

2. Babar A. M., Verner J. M., Nguyen P. T. (2007). "Establishing and maintaining trust in software outsourcing relationships: An empirical investigation" The Journal of Systems and Software, Vol. 80, pp. 1438-1449.
3. Bradford M. and Florin J. (2003). "Examining the role of innovation diffusion factors on the implementation success of ERP systems" International Journal of Accounting Information Systems, Vol. 4, pp. 205-225.

4. Bruque S. and Moyano J. (2007). Organizational determinants of IT adoption and implementation in SMEs: The case of family and cooperative firms. Technovation, Vol. 27, pp. 241-253.

5. Connor-Linton, J. (2003) Chi-Square Tutorial. Retrieved June $20^{\text {th }}, 2005$ from http://www.georgetown.edu/faculty/ballc/webt ools/web_chi_tut.html

6. Duh, R-R., Chow C. W. \& Chen, H. (2006). Strategy, IT applications for planning and control, and firm performance: The impact of impediments to IT implementation. Information and Management. 43(8), 939-949.

7. Evans D. and Yen D. C. (2005). "Egovernment: An analysis for implementation: Framework for understanding cultural and social impact". Government Information Quaterly, Vol. 22, pp. 354-373.

8. Kim H. S. and Kim Y. G. (2008). "A CRM performance measurement framework: its development process and application" Industrial Marketing Management, Article in Press, pages 13.

9. Gottschalk P. (1999). "Implementation predictors of strategic IS plans", Information and Management, Vol. 36, pp. 77-91.

10. Hendricks K. B., Singhal V. R. and Stratman J. K. (2007). The impact of enterprise systems on corporate performance: A study of ERP, SCM, and CRM systems implementations, Journal of Operations Management, Vol. 25, pp. 35-82.

11. Hwang M. I. and Thorn R. G. (1999). "The effect of user engagement on system success: A meta-analytical integration of research findings" Information and Management, Vol. 35, pp. 229-236.

12. Kettinger, W. J., Grover, V., Guha, S. and Segars, A. H. (1994), Strategic Information Systems Revisited: A study in sustainability 
and performance, MIS Quarterly, (March) pp. 31-58.

13. McHaney R. \& Cronan T. P. (2000). "Toward an empirical understanding of computer simulation implementation success", Information \& Management, Vol. 37, pp. 135151 .

14. McKnight D. H., Choudhury V. and Kacmar C. (2002). "The impact of initial consumer trust on intentions to transact with a web site: a trust building model" Journal of Strategic Information Systems, Vol. 11, pp. 297-323.

15. Mendoza L. E., Marius A., Perez M. and Griman A. C. (2007). "Critical success factors for a customer relationship management strategy" Information and Software Technology. Vol. 49, pp. 913-945.

16. Oza N. V., Hall T., Rainer A. and Grey S. (2006). "Trust in software outsourcing relationships: An empirical investigation of Indian software companies" Information and Software Technology, Vol. 48, pp. 345-354

17. Ozgener S. and Iraz R. (2006). Customer relationship management in small-medium enterprises: The case of Turkish tourism industry. Tourism Management, Vol. 27, pp. 1356-1363.
18. Ratnasingham P. and Kumar K. (1999). "Trading partner trust in electronic commerce participation" ICIS. Proceedings of the Twentieth International Conference on Information Systems. 1(1), 678-691.

19. Sharma R., Yetton P. W., Zmud R. W. (2008). "Implementation costs of IS-enabled organizational change", Information and Management, Vol. 18, pp. 73-100.

20. Santhanam, R. and Hartono, E. (2003) Issues in Linking Information Technology Capability to Firm Performance, MIS Quaterly, Vol. 27, No. 1, pp. 125-153.

21. Teo T. S. H., Devadoss P. and Pan S. L. (2006). " Towards a holistic perspective of CRM implementation:" A case study of the Housing and Development Board, Singapore" Decision Support Systems, Vol. 42, pp. 16131627.

22. Wybo, M. (2007). "The IT sales cycle as a source of context in IS implementation theory", Information and Management, Vol. 44, pp. 397-407.

\section{APPENDIX}

Table 7. Impact of vendor trust on peer influence

\begin{tabular}{|c|c|}
\hline $\begin{array}{l}\text { Coded } \\
\text { Messages }\end{array}$ & Definition of Messages \\
\hline CSC & CRM was developed by somebody who was an actually consultant for the SBDC \\
\hline CSNC & $\begin{array}{l}\text { Several states such as New York, Florida, and Texas had developed their own system. They had used a } \\
\text { service of companies which are not consultant for the SBDC. }\end{array}$ \\
\hline APA & I asked my peers what systems were best recognized by our national association. \\
\hline APNA & There were about 6 different options within the US; one was CRM, one was Winkat system. \\
\hline GAD & I gathered all of that data to see what my peers were using. \\
\hline GAND & $\begin{array}{l}\text { General speaking, users who used Winkat found it to be adequate but not as responsive to customized } \\
\text { needs as those who were used Center IC. }\end{array}$ \\
\hline UCI & $\begin{array}{l}\text { A consultant for the SBDC developed CRM to address a specific state need to verify the accuracy of their } \\
\text { original offices is very comforting fact that I found probably the strongest reason somebody would buy } \\
\text { CRM over a competing product. }\end{array}$ \\
\hline UCNI & $\begin{array}{l}\text { The adoption of a competitive product or software created the risk of being the first to use that new } \\
\text { system. }\end{array}$ \\
\hline
\end{tabular}


$\underline{\text { Table 8. Impact of peer influence on implementation success }}$

\begin{tabular}{|l|l|}
\hline $\begin{array}{l}\text { Coded } \\
\text { Messages }\end{array}$ & Definition of Messages \\
\hline CCD & Currently, 28 states use CRM software \\
\hline CCND & $\begin{array}{l}\text { Several states such as New York, Florida, and Texas had used systems which were privately designed } \\
\text { and proprietary to those states. }\end{array}$ \\
\hline SAA & $\begin{array}{l}\text { The use of CRM by other SBDCs helps to increase the accuracy of the assessment of their } \\
\text { organizational performance }\end{array}$ \\
\hline SANA & The use of another system by some SBDCs boost their consultants productivity. \\
\hline MMP & $\begin{array}{l}\text { So I do thing the majority of my peers were converting to CRM because they found the flexibility of the } \\
\text { template and the verification much more accessible than a competing product. }\end{array}$ \\
\hline MMNP & \begin{tabular}{l} 
Some competitive products we did try in the past were not flexible as CRM \\
\hline
\end{tabular}
\end{tabular}

Table 9. Impact of vendor trust on top management support

\begin{tabular}{|l|l|}
\hline $\begin{array}{l}\text { Coded } \\
\text { Messages }\end{array}$ & $\begin{array}{l}\text { Definition of Messages } \\
\text { WTP }\end{array}$ \\
\hline WTNP & $\begin{array}{l}\text { We also had a tech person from local university make sure that the system would not interfere and } \\
\text { would be of value and would've been worth of inclusion in our organization. }\end{array}$ \\
\hline LPD & $\begin{array}{l}\text { Irealized maybe in the advantage of ND SBDC to use CRM because we didn't have the technological } \\
\text { We also had the Legal purchasing department at local university look over the licensing ag reements for } \\
\text { CRM in order to make sure that they fit to our host organization requirements. }\end{array}$ \\
\hline LPND & We used the information provided by the Center IC vendor to make our final decision. \\
\hline CIP & $\begin{array}{l}\text { CRM was developed by an SBDC person. That person was known by our organization because it was } \\
\text { involved in the maintenance of the old system. }\end{array}$ \\
\hline CINP & All members of the top management did not know the vendor of CRM. \\
\hline WDC & $\begin{array}{l}\text { We decided to use CRM because we didn't have the budget to redo the system and maintain it in order } \\
\text { to keep up with the federal standards. }\end{array}$ \\
\hline WDNC & The old system has communication problems with the federal system. \\
\hline ARW & Another reason why we wanted to use CRM is because it is widely use and recognized. \\
\hline ARNW & $\begin{array}{l}\text { SBDC are using competitive systems other than CRM because they have a big budget and they are very } \\
\text { large or big states. }\end{array}$ \\
\hline CCA & The costs of continual updating of code of the old system were not worth the investment in a program. \\
\hline CCNA & Center IC is designed for far less complicated transmission \\
\hline
\end{tabular}

Table 10. Impact of top management support on implementation success

\begin{tabular}{|l|l|}
\hline $\begin{array}{l}\text { Coded } \\
\text { Messages }\end{array}$ & Definition of Messages \\
\hline CIS & CRM implementation receives strong active support from top management. \\
\hline CINS & $\begin{array}{l}\text { I really didn't know, we had a conference call that I mentioned before that I sat on we discussed } \\
\text { purchasing but as far as issues related, the state director, possibly the assistant state director made the } \\
\text { decision to purchase any of the new software. }\end{array}$ \\
\hline ETC & CRM implementation effort has been closely tied to the competitive strategies of the firm. \\
\hline ETNC & $\begin{array}{l}\text { I think it was a necessity just due to the fact that the system we currently had 1-Site it has been so } \\
\text { unmanageable as SBA reason regard that we had to change sooner or later, so I think it was just } \\
\text { prudent to do it right now. }\end{array}$ \\
\hline SWD & $\begin{array}{l}\text { The success of CRM implementation efforts was due to the active championing by a key senior } \\
\text { management person. }\end{array}$ \\
\hline SWND & $\begin{array}{l}\text { I cannot tell that because I usually report to my boss and my boss reports to the state director. } \\
\text { trainings and demos about the new systems }\end{array}$ \\
\hline OPI & $\begin{array}{l}\text { I remember that our state director organized a demo, all local meetings are organized by the state } \\
\text { director but I do not participate to the national meeting. So it difficult to report on that. }\end{array}$ \\
\hline OPNI & $\begin{array}{l}\text { After watching the team in Arkansas who used CRM, I realized may be in the advantage of ND SBDC } \\
\text { to implement it. }\end{array}$ \\
\hline AWA & We all did not go to Arkansas. Only our state director did. So I have no clue about what happened in \\
\hline AWNA
\end{tabular}




\begin{tabular}{|l|l|}
\hline & Arkansas. \\
\hline WAV & $\begin{array}{l}\text { I went on accreditation visit to see how the accreditation team uses the reporting data in their } \\
\text { determination of quality of all programs. }\end{array}$ \\
\hline WANV & I believe our director would rather go to those meetings in group. \\
\hline
\end{tabular}

Table 11. Impact of vendor trust on user participation

\begin{tabular}{|l|l|}
\hline $\begin{array}{l}\text { Coded } \\
\text { Messages }\end{array}$ & Definition of Messages \\
\hline THA & There is help available from vendors in case of software error \\
\hline THNA & I would like to see a more customized help, I mean a help which is adjusted to our particular need. \\
\hline TEA & There is easy access to education facilities to help in utilizing the system \\
\hline TENA & Ifound the documentation very complex. \\
\hline FCI & $\begin{array}{l}\text { The fact that CRM was developed by somebody who does the same job as us and who understands our } \\
\text { priority. }\end{array}$ \\
\hline FCNI & We will still participate because our executive has approved the vendor. \\
\hline BVR & I believe in the vendor reputation because he is a country wide known vendor. \\
\hline BVNR & $\begin{array}{l}\text { Since the vendor is well known by our executive, I think that has some impact on the final decision. It } \\
\text { seems to me like the vendor popularity did not play a big role.t }\end{array}$ \\
\hline BSR & I believe in the vendor reliability because his software is in use in already many states. \\
\hline BSNR & I cannot say anything about that because some states are not using our vendor software \\
\hline
\end{tabular}

Table 12. Impact of user participation on the implementation success

\begin{tabular}{|l|l|}
\hline $\begin{array}{l}\text { Coded } \\
\text { Messages }\end{array}$ & Definition of Messages \\
\hline CMH & $\begin{array}{l}\text { Company's management has not taken notice of my opinion and my needs before deciding to buy and } \\
\text { implement the system. }\end{array}$ \\
\hline CMNH & We had attended the software demonstration session \\
\hline TSD & $\begin{array}{l}\text { The state director, possibly the assistant state director had more direct involvement and a lot of other } \\
\text { consultants I know didn't really have any involvement in the decision to purchase any of the new } \\
\text { software. }\end{array}$ \\
\hline TSND & $\begin{array}{l}\text { I have actively participated in the system's buying decision process } \\
\text { TTJ } \\
\text { for themselves but also for any interns, any people that have been hired. They do not have to sit down } \\
\text { in the sessions for again and again. }\end{array}$ \\
\hline TT NJ & $\begin{array}{l}\text { We received training and the software was made available for us to use it and report on that. } \\
\text { the product fit with what they needed it. There was a vote taken and they decided that they would prefer } \\
\text { CRM. }\end{array}$ \\
\hline DRO & $\begin{array}{l}\text { There is at the state level, I do not know if that would go down to the individual request or not if you } \\
\text { have time to do that, I hope so but, I am not sure at this point. }\end{array}$ \\
\hline DRNO & $\begin{array}{l}\text { I would say for the technical assistance, not to make it so overly technical at least in the early stages, } \\
\text { we just need to know the basic outline, how to do steps A, B, C and keep continually. }\end{array}$ \\
\hline WTC & We do have on-line access to the vendor tech staff as we adapt the data. \\
\hline WTNC
\end{tabular}

